\title{
RAZIM, J. Věrní Přemyslovci a barbarští Čechové.
}

\author{
Praha: Leges, 2017, $416 \mathrm{~s}$.
}

V oboru starších českých právních dějin se najde jen málo témat, jež by v minulosti vyvolala tolik kontroverzí jako státoprávní vztah českého státu a Svaté říše římské. Na vině byla především politická objednávka - česko-německé vztahy byly v průběhu 19. a 20. století značně komplikované, procházely dramatickými turbulencemi a celá řada historiků se v tomto kontextu bud' vědomě, nebo přinejmenším mimoděk snažila o to, aby jejich interpretace a závěry patřičně podporovaly aktuální zájmy na př́slušné straně státní hranice. Posledním významným paradigmatickým př́spěvkem české historiografie $\mathrm{k}$ diskuzi se stala útlá monografie Václava Vaněčka, vydaná hned v roce 1945 - v ní byl poměr mezi Čechami a Řiší v období raného a vrcholného středověku označen za vztah povýtce politický, v němž se právo redukovalo na utilitární interpretační prostředek. Rozhodně zde bylo také odmítnuto jakékoliv uznání lenní podřízenosti z české strany. ${ }^{1}$ Tyto teze rezonují na českých právněhistorických pracovištích prakticky dodnes.

Recenzovanou publikaci lze rozhodně považovat za velmi významný př́spěvek $\mathrm{k}$ naznačenému tématu a zároveň sympatický pokus oživit diskuzi, která byla $\mathrm{v}$ českém prostředí pod vlivem Vaněčkovy autority do značné míry utlumena. Jednoznačným kladem je skutečnost, že autor, mladý brněnský historik Jakub Razim, se mohl při psaní opírat nejen o své právní vzdělání, ale že je zároveň absolventem klasického vzdělání historického. To mu zejména umožnilo reflektovat některé moderní západoevropské historiografické proudy, jejichž společným jmenovatelem je ústup pozornosti napjaté ke konkrétním historickým událostem a procesům, a naopak akcentování jednotlivce, jeho vnitřního světa a prožitku, stejně jako komunikačních a interakčních schémat uvnitř společnosti. Přejímání antropologických, kulturněhistorických a dalších podobných podnětů do právněhistorické práce je nepochybně zajímavým osvěžením klasické juristické metodologie, která v období staršího středověku naráží na řadu limitů.

Jedním z produktů mohutného „cultural turn“, ovládajícího západoevropské historické bádání, je také kulturněhistorická analýza práva, vycházející z poznatku o diametrálně odlišném fungování středověkého světa, jehož právní základy byly modernímu právnímu řádu na hony vzdáleny. Klíčovou roli v něm nehrály ani právní předpisy, ani jiné klasické právní prameny, ale spíše formalizované rituály, jejichž opakování utvářelo nezbytnou míru právní jistoty ve společenských vztazích. ${ }^{2}$ I když v jednotlivých aspektech lze jistě

VANĚČEK, V. Stát Přemyslovcui a středověká ,řriše“. Praha: Melantrich, 1945.

Zde je třeba odkázat především na monografii STOLLBERG-RILINGER, B. Rituale. Frankfurt am Main New York: Campus, 2013; či kolektivní práci STOLLBERG-RILINGER, B. - NEU, T. - BRAUNER, C. 
naznačený výzkumný proud z právněhistorického hlediska podrobit kritice či přinejmenším přijímat s rezervou jeho východiska, není sporu o tom, že může být pro starší právní dějiny zároveň v mnoha ohledech inspirativní. Je-li totiž předmětem zájmu právní historie fenomén práva, pak se při jeho zkoumání rozhodně nelze omezovat na podobu právních norem platných v jednotlivých historických epochách, ale je nutno vnímat a mapovat také jejich reálné působení. Neboli, rovinu „law in books““ je třeba neustále konfrontovat s „law in action“, což v sobě obnáší hledání skutečného vlivu práva na život společnosti a jeho vnímání ze strany současníků.

Právě pro starší středověké období platí přitom nepochybně, že klasických právních textů je zachováno minimum a že podobu práva je třeba - ovšem se značnou opatrností vyvozovat z reálných událostí, zaznamenaných takřka výhradně v pramenech narativní povahy. Což znamená, že metodologická výzbroj historie zde nachází větší uplatnění než prostředkový arzenál klasické jurisprudence. Z tohoto pohledu je velmi důležité, že je autor více než dobře schopen př́stupy obou vědních disciplín podle potřeby kombinovat.

Knihu zahajuje hutná kapitola Čechy a Říše (s. 11-40), víceméně suplující - poněkud nekonvenčně - absentující úvod. Její první část představuje komentovaná bibliografie zahraniční, dominantně německé literatury, která byla v posledních desetiletích věnována problematice středověkého mezinárodního práva, resp. která reprezentuje moderní př́ístupy ke zkoumání středověkého života včetně fenoménu práva. Autor se zde poměrně velmi zřetelně přihlásil k inspiraci konceptem „Vorstellungsgeschichte“ (dějin představ), ${ }^{3}$ což ho vedlo k vymezení tří různoběžných rovin zkoumání reality: 1. východní politika Říše (události), symbolická česko-řŕšská komunikace a s ní spojené rituály (struktury) a dobové koncepce zapojení Čech do politického prostoru středovýchodní Evropy, resp. oblasti politického vlivu Říše (představy). Vzhledem k proměnám říšské politiky, k nimž došlo po nastoupení dynastie Štaufů na říšský trůn, se přitom rozhodl omezit svůj zájem na starší, otonsko-sálskou epochu. Následně vysvětlil, z kterých narativních pramenů bude další analýza vycházet, a konečně si v závěru kapitoly vymezil tři hypotézy, k ověření jejichž pravdivosti má další rozbor směřovat. A sice, že 1. politické elity Čech a Říše se sdružovaly v rituální společenství, 2. české země byly v Říši vnímány jako její součást, byt' do jisté míry specifická, a přemyslovští panovníci v důsledku toho za plnoprávná říšská knížata, 3. ř́šsko-české vztahy neměly ryze politický charakter a nebyly primárně budovány z pozice síly, ale podléhaly všeobecně přijímaným regulativům.

Následujících pět kapitol je pak podrobnou analýzou a interpretací toho, jak byly Čechy a jejich vztah $\mathrm{k}$ Říši zachyceny ve vybraných narativních dílech fundamentálního významu. Postupně jsou takto podrobně zkoumány Tři knihy saských dějin Widukinda z Corvey (s. 41-90), Kronika Dětmara z Merseburgu (s. 91-172), Altašský letopis (s. 173-236), Letopisy Lamperta z Hersfeldu (s. 237-272) a Hildesheimský letopis (s. 273-314). Tento výběr má samožrejmě za následek určitou jednostrannost, nebot' všechna uvedená díla reprezentují výhradně německou reflexi zkoumané problematiky, což nevyhnutelně implikuje jistou tendenčnost. Toho si byl autor vědom a otevřeně tuto skutečnost avizoval, přičemž zároveň ohlásil své odhodlání se s ní co nejpečlivěji vyrovnat (s. 28-29). I když

(eds.). Alles nur symbolisch? Bilanz und Perspektiven der Erforschung symbolischer Kommunikation. Köln - Weimar - Wien: Böhlau, 2013.

3 Základním dílem je v tomto ohledu GOETZ, H.-W. Vorstellungsgeschichte. Gesammelte Schriften zu Wahrnehmungen, Deutungen und Vorstellungen im Mittelalter. Bochum: Dieter Winkler, 2007. 
samozřejmě nelze přehlédnout pomalejší cestu k písemné kultuře v Čechách (a slovanských zemích obecně) ve srovnání se západní Evropou a z toho se odvíjející absenci srovnatelné pramenné základny na naší straně hranice, rozhodně se nabízí otázka, zda autor přeci jen neměl zařadit i kapitolu věnovanou kronice pražského kanovníka Kosmy, jehož život se z nemalé části s autorem sledovaným obdobím překrývá a jehož tak lze alespoň částečně vnímat za významného „očitého svědka“. V tomto směru si jeho volba (či spíše nevolba) zasloužila pregnantnější zdůvodnění.

Autor se ve všech výše uvedených kapitolách držel s chvályhodnou systematičností jednotného schématu. Nejprve představil dotyčný pramen, popsal jeho provenienci a tam, kde to bylo možné, též osobnost autora, zhodnotil hodnověrnost kroniky (zejména in specie ve vztahu k českému prostředí) a provedl přehled toho, v jaké míře a v jakém kontextu jsou v něm záležitosti Českého knížectví a jeho vládnoucích elit reflektovány. Podkapitoly „Ideový koncept Čech a ř́šš“ usilují o deskripci jakéhosi pomyslného státoprávního modelu, vyrůstajícího z textu zkoumaných pramenů, přičemž autorovy úvahy jsou znovu podepřeny bohatými sondami do soudobé evropské historiografie raného středověku a jejích metodologických impulzů nejrůznějšího druhu. V závěrečných podkapitolách „Rituální společenství Čech a říše“ pak autor podrobně analyzuje konkrétní, kronikami a letopisy zachycené události, které dává do dobového politického a právního kontextu a snaží se nalézat paralely v širším ř́řšském prostředí. O tom, jaké interakce a rituály jsou zkoumány, vypovídají velmi ilustrativně dodatky k názvům těchto podkapitol, resp. názvy jejich jednotlivých částí (Přemyslovská deditia, Gratia regis, Vladivojova investitura roku 1002, Jaromírova investitura roku 1004, Jaromírovo deditio roku 1012, Břetislavovo deditio roku 1041, Darovací rituály, Dary a tributy, Diplomatické dary, Dary za věrnost, Politické procesy).

V Závěru (s. 315-326) autor zrekapituloval výsledky dílčích analýz a zdůraznil některé jejich společné rysy. Na prvním místě upozornil na určitou dichotomii řeči pramenů, které na ,gens" Čechů hleděly jako na svébytnou pospolitost, odlišnou od germánského obyvatelstva Říše, avšak Přemyslovce vnímaly jako říšská knížata, respektující autoritu rímských císařů (králů). Jejich vzájemnou komunikaci v podobě symbolických gest, výroků a rituálů lze přitom podle autora - v souladu se závěry některých historiků německých - chápat jako standardní prostředek dobové diplomacie, resp. „mezinárodního práva“, tedy jako jednání, která navzdory absenci písemné formy nepostrádala normativní rozměr. Již v 10. století se začal v říšsko-českých vztazích prosazovat rituál zvaný deditio, jehož podstatou bylo vyhledávání a zpravidla též získávání milosti od mocnějšího partnera za cenu formalizovaného pokoření, od století následujícího pak prameny opakovaně dosvědčují přechodový rituál investitury, který lze podle autorova velmi přesvědčivě vyargumentovaného názoru těžko chápat jinak než jako udílení léna ze strany ř́íšských vládců a zároveň slib vazalské věrnosti přemyslovských knížat. Do třetice pak podle autora víceméně všechny prameny poukazují na to, že součástí říšsko-české koexistence byl také rozvinutý systém darů, který ale $\mathrm{v}$ zásadě fungoval na principu do ut des. Také z něho vyplývá zařazení Přemyslovců do okruhu řŕšské nobility, participujícího na ustálených rituálech (v německé literatuře se užívá pojmu „Ritualgemeinschaft"), přičemž jejich postavení zde bylo rovněž v jistém smyslu podřízené císařủm, nebot' předávání darů - v obou směrech - probíhalo zásadně na ř́ršské půdě.

Celé pojednání autor zakončil poměrně nesmlouvavým konstatováním, že „z probrané látky se tudíž jen stěží dobereme stanoviska zastávaného právními historiky, již kráčejí 
ve šlépějích Václava Vaněčka a tvrdí, že evropský geopolitický prostor, v němž se rozkládalo otonsko-sálské impérium a přemyslovský ,státeček', byl vyplněn právním vakuem, že postrádal elementární ,pravidla hry“ a že silnějším ,hráčům‘ ponechával volnost, aby se chovali ke slabším, jak se jim zlíbí“ (s. 326). Na první pohled může snad někomu takovéto vyústění připadat až př́liš neuctivé k autoritám, zvláště od autora poměrně mladého. $\mathrm{Na}$ druhou stranu je ale tř̌eba vidět, že z jeho díla čiší za prvé vynikající znalost jak dobových pramenů, tak relevantní zahraniční literární produkce (a to jak z oboru právních dějin, tak především jiných př́buzných historických disciplín) a za druhé promyšlené úsilí dobrat se za použití co nejširšího spektra metodických postupů důkladnému porozumění dobových událostí, jejich vnímání a právní interpretaci. Jistě, interdisciplinární (a zejména výrazně kulturně-historický) př́stup může v ryze juristických kruzích budit určité pochybnosti (podle soudu recenzenta byla např́klad ne zcela dostatečně rozebrána souvztažnost mezi „právními rituály“ a fenoménem právního obyčeje jakožto historicky prvotního pramene práva, patřícího k základním pojmoslovným institutům právní historie), ovšem interdisciplinární spolupráce a vzájemné ovlivňování je nepochybně trendem, který může historiografii výrazně posouvat vpřed.

Není každopádně sporu o tom, že problematika raně středověkých česko-německých vztahů si zaslouží, aby byla po desetiletích utlumení v české právní historii znovu otevřena a podrobena další diskuzi, v níž je možno s Věrnými Přemyslovci a barbarskými Čechy souhlasit, či nesouhlasit, ale rozhodně je třeba brát je vážně. Tím spíše, že nejde o první pokus podrobit tuto významnou část českých dějin relativně hluboké reinterpretaci. ${ }^{4}$

doi: 10.14712/2464689X.2019.19

Marek Starý

4 Viz velmi podnětnou studii KALHOUS, D. Čechy a říše: problém pramenů nebo historiografie? Český časopis historický, 2013, 3/CXI, s. 481-516. 